\title{
EKSPLOITASI PEKERJA ANAK DI INDONESIA DAN REKONSTRUKSI ARAH KEBIJAKAN SOSIAL
}

\author{
Miftahul Jannah \\ Email: jannahmiftahul263@gmail.com
}

\begin{abstract}
The children are persons who have the age under 18-years old who havestill the right to be protected from life-threatening matters, from acts of exploitation, and the things that interfere their future. Remembering that the childhood is a growth process, both physical and mental, ideally children should avoid the various behaviors that interferetheir growth. Therefore, children need to be guaranteed their rights, and play. In this paper, the writer wants to describe the forms of exploitation of children such as the loss of children's rights so they must go the world of work due to poverty problems which become main foundation of children to participate in fulfilling their needs. The factors of exploitation are certainly due to the lack of understanding of the head of the family about the importance of children's education. Therefore it is important to reconstruct the social policy purposes of the children, in order to avoid exploitation actions which can disturb the growth of a children's lives, by the reconstruction of social policy of the government, it is able to restore the rights of children in life, so that the fulfillment of all needs and the creation of welfare for children.
\end{abstract}

Keywords: Children, exploitation, social policy reconstruction

\section{A. Pendahuluan}

Anak adalah generasi yang akan menjadi penerus bangsa. Mereka harus dipersiapkan dan diarahkan sejak dini agar dapat tumbuh dan berkembang menjadi anak yang sehat jasmani dan rohani, maju, mandiri, dan sejahtera menjadi sumber daya yang berkualitas dan dapat menghadapi tantangan di masa yang akan datang. Mengingat masa anak-anak merupakan proses pertumbuhan, baik fisik maupun 
jiwa, maka idealnya anak-anak harus terhindar dari berbagai prilaku yang menggangu pertumbuhan yang mengakibatkan tidak anak harus kehilangan hak-haknya. Salah satu bentuk hilanganya hak-hak anakadalah secepatnya anak-anak terjun ke dunia kerja. Dari satu sisi kondisi tersebut sungguh memprihatinkan. Akan tetapi di sisi lain,memperkerjakan anak-anak bagi sebagian masyarakat merupakan kebutuhan, terutama bagi masyarakat miskin.Oleh karena itu, pekerja anak tidak dapat dihapuskan begitu saja, tetapi harus dikurangi secara bertahap lewat perencanaan yang matang dan hati-hati. ${ }^{1}$

Fenomena pekerja anak merupakan gambaran betapa kompleks dan rumitnya permasalahan anak. Terlepas dari semua hal tersebut, penghargaan, penghormatan, serta perlindungan Hak Asasi Manusia (HAM) digaung- gaungkan di penjuru dunia. Namun, faktor-faktor lain seperti kegagalan dalam pranata sosial turut menunjukkan ketidakmampuan pemerintah. Dalam konteksnya, sebenarnya anak mempunyai hak yang bersifatasasisebagaimanayangdimiliki orang dewasa. Banyak anak-anak yang berada di bawah umur menjadi objek dalam pelanggaran terhadap hak-hak anak akibat pembangunan ekonomi yang dilakukan .

Di negara kita, pekerja anak dapat dilihat dengan mudah di pertigaan atau di perempatan jalan. Pandangan kita jelas tetuju pada sekelompok anak yang mengamen, mengemis, atau mengais rezeki di jalanan. Itu hanya sedikit dari betapa mirisnya kondisi anak-anak Indonesia. Masih banyak yang tidak terlihat jelas, upayaupaya pengeksploitasian anak-anak di negeri ini bahkan dapat disejajarkan dengan tindakan kriminal. Mereka di eksploitasi sebagai pekerja kasar konstruksi dan tambang tradisional, penyelam mutiara, penculikan dan perdagangan anak, kekerasan anak, penyiksaan anak dan bahkan pelacur komersial.

\section{B. Metode kajian}

Kajian ini, menggunakan penelitian berdasarkan literatur atau penelitian perpustakaan (library research). Artinya suatu studi dengan mengkaji buku-buku, jurnal dan data-data tertulisyang ada kaitannya dengan kesejahteraan sosialyang diambil dari semua sumber yang berasal pada bahan tertulis yang berkaitan dengan permasalahan dalam judul di atas. Metode pengumpulan data,karena pengkajian ini adalahpenelitian kepustakaan (library research), maka data yang diambil berasal dari berbagai sumber tulisan, baik dari buku,majalah, dan tulisan ilmiahyang bersangkutan denganmateri yang dibahas. Metode analisis data yang digunakkan adalah metode deskriptif analitis. Metode deskriptif analitis adalah suatu usaha untuk mengumpulkan danmenyusun

1 Edi Suharto. Analisis Kebijakan Publik (Bandung: Alfabeta, 2012). Hlm. 211 
suatu data, kemudian diusahakan adanya analisis danpenafsiran data. ${ }^{2}$

\section{Kerangka Konseptual}

\section{Gambaran umum Eksploitasi Anak}

Eksploitasi anak menunjuk pada sikap diskriminatif atau perlakuan sewenang-wenang terhadap anak yang dilakukan oleh keluarga ataupun masyarakat. Sebagai contoh, memaksa anak untuk melakukan sesuatu demi kepentingan ekonomi, sosial atau politik tanpa memperhatikan hak-hak anakuntukmendapatkanperlindungan sesuai dengan perkembangan fisik, psikisnyadanstatussosialnya. Misalnya, anak dipaksa untuk bekerja di pabrikpabrik yang membahayakan dengan upah rendah dan tanpa peralatan yang memadai, anak dipaksa untuk berkerja di jalanan, atau dipaksa melakukan pekerjaan-pekerjaan rumah tangga melebihi batas kemampuannya. ${ }^{3}$

\section{Faktor Penyebab dan Pendorong terjadinya eksploitasi terhadap anak di Indonesia}

Faktor penyebab dan pendorong permasalahanpekerjaanakdiIndonesia merupakan interaksi dari berbagai faktor di tingkat mikro sampai makro, dari faktor ekonomi sosial budaya sampai pada masalah politik. Adapun faktor-faktor penyebab dan pendorong

2 Winarno Surachmad,Pengantar penelitian ilmiah Dasar (Bandungtarsito:1985) hlm.139

3 Edi Suharto. Membangun Masyarakat Memberdayakan Rakyat (Bandung, PT.Raflika Aditama 2010).hlm 161 permasalahan pekerja anak menurut hasil penelitian(JARAK) Jaringan Penanggulangan Pekerja Anak adalah faktor kemiskinan.

Rendahnya ekonomi keluarga merupakan faktor dominan yang menyebabkan anak-anak terlibat mencari nafkah. Anak sering menjadi sumber penghasilan yang sangat penting. Bahkan dalam banyak hal, pekerja anak dipandang sebagai mekanisme survival untuk mengeliminasi tekanan kemiskinan yang tidak terpenuhi dari hasil kerja orangtua.Terlibatnya anak dalam kegiatan ekonomi juga karena adanya dorongan untuk membantu meringankan beban orangtua, bekerja untuk mendapatkan penghormatan dari masyarakat, juga keinginan menikmatihasil usaha kerja, merupakan faktor-faktor motivasi anak ikut berkerja.

Dari beberapahasil penelitian penulis tentang pekerja anak dapat disimpulkan beberapa faktor penyebab pekerja anak, antara lain:

a. Kemiskinan,ILO dan UNICEF (1994) menyebutkan bahwa kemiskinan merupakan akar permaslahan terdalam dan faktor utama anak-anak terjun ke dunia kerja.

b. Adanya pihak-pihak tertentu yang tega mengeksploitasi pekerja anak.

c. Masalah psikososial

d. Faktor budaya 


\section{e. Faktor globalisasi}

\section{Data Statistis Jumlah Pekerja Anak}

Berdasarkan data dari BPS pada bulan Oktober 2000, jumlah pekerja anak usia 10-14 tahun tercatat sebanyak 2,05 juta, dan terus turun hingga pada Oktober 2005 menjadi 1,64 juta jiwa. Setelah krisis, pada tahun 2006 terjadi peningkatan menjadi 1,81 juta dan pada tahun 2007 mencapai angka 2,21 juta jiwa, sedangkan pada tahun 2008 mencapai angka 5,75 juta jiwa. ${ }^{4}$

Sedangkan menurut data dari BPS per Februari 2008, jumlah (PRT) di Indonesia mencapai 1.714.437 jiwa, dan 202.235 jiwa (11,79\%) diantaranya adalah pekerja rumah tangga anak (PRTA) yang berumur dibawah 18 tahun, dan $90 \%$ diantaranya adalah PRT Perempuan. Pada beberapa wilayah persentase jumlah PRT perempuan bahkan lebih tinggi lagi. Hasil penelitian International Labour Organization-Internasional Progamme On The Elimination Of Chil Labour / ILO-IPEC pada 234 responden Jakarta timur dan bekasi menunjukkan bahwa 226(96,7\%) PRT Berjenis kelamin perempuan. ${ }^{5}$

Kemudian potensi angka putus sekolah akibat krisis, berdasarkan perkiraan Bappenas meningkat

4 Haryadi, Dedi, dkk. Buruh Anak dan Dinamika Industri Kecil,(Alkatiga, Bandung).hlm. 22.

5 Bunga-bunga diatas Padas, Fenomena Pekerja Rumah Tangga Anak Di Indonesia. ILO/ IPEC $2004 \mathrm{hlm} .21$ tajam, dari 2,8 juta menjadi 8 juta pertahun.Dan yang memprihatinkan, bersamaan dengan makin tingginya kecenderungan anak putus sekolah, adalah kemungkinan bertambahnya anak-anak usia sekolah yang terpaksa bekerja untuk membantu ekonomi keluarga.

Terkait dengan jumlah eksploitasi pekerja anak di Indonesi yang semakin tahun semakin mengalami peningkatan. Salah satu upaya yang dilakukan Pemerintah terkait dengan permasalahan eksplotasi pekerja anakmenyadarkan masingmasing anggota keluarga untuk tidakmembiarkan anak terjun kedalam dunia kerja.Sehingga Negara berkewajiban memenuhi seluruh hakhak masyarakat dengan menyediakan lapangan pekerjaan, mengatur upah, dan memberikan perlindungan keamanan serta jaminan social lainya.

\section{Bentuk Rekonstruksi Kebijakan Sosial (Pilihan-Pilihan Kebijakan)}

Kebijakan sosial adalah suatu ketetapan yang memuat prinsipprinsip untuk mengarahkan cara-cara bertindak yang dibuat secara terencana dan konsisten dalam mencapai tujuan tertentu. ${ }^{6}$ Sebagai suatu produk, kebijakan sosial adalah hasil dari proses perumusan kebijakan atau perencanaan sosial. Dalam pengertian ini kebijakan sosial mencakup segala bentukperatura, perundang-undangan

6 Edi Suharto. Analisis Kebijakan Public. (Bandung.Alfabeta.2012).hlm.7 
atau proposal program yang berfungsi sebagai pedoman dalam melaksanakan berbagai kegiatan atau proyek.

Dalam menyingkapi permaslahan eksploitasi pekerja anak di Indonesia, maka ada beberapa alternative kebijakan pemerintah dalam merekontruksi kebijakans osial guna mengatasi permasalahan di atas antara lain:

a. Membebaskan uang sekolah bagi anak-anak terutama yang berasal dari keluarga miskin merupakan langkah yang tepat, meskipun hal ini tidak cukup untuk meransang ataumempertahankananak-anak tersebut untuk tetap sekolah. Oleh karena itu perlu disertai dengan memberikan berbagai keperluan lain seperti: seragam, buku-buku, alat-alat tulis, dan sebagainya.

b. Jenis pendidikan pun tidak harus pendidikanformal, terutamabagi pekerja anak yang telah putus sekolah, tetapi dapat berbentuk keterampilanya , seperti: kursus menjahit, kursus montir, kursus elektronik, dan sebagainya yang siap pakai.

c. Pemerintah sebaiknya membuat batasan upah terendah bagi anak-anak. Hal ini sangat mendesak untuk diberlakukan karena Undang-undang ketenagakerjaan yang sekarang berlaku, sesungguhnya dapat disartikan bahwa pemerintah telah melegalkan pekerja anak. Maka untuk menghindari eksploitasi anak berdasarkan upah maka perlu diatur jam kerja dan upah buruh anak harus segera dibenahi.

d. Meskipun masih terdapat tradisi yang kuat pada pendidikan anak yanglebih formal dan terorganisir tentunya trasdisi ini perlahan menghilang setelah anak sudah tidak mampu melanjutkan sekolah disebabkan karena kendala masalah perekonomian keluarga dan lingkungan social. ${ }^{7}$

\section{Peraturan Perundang-Undangan di Indonesia dalam memberikan perlindungan kepada anak}

Pemerintah memang sudah melakukan berbagai upaya dalam hal perlindungan anak ini, dengan mengeluarkan berbagi macam bentuk keputusandankebijakan-kebijakandalam mengatasi permasalahan yang di hadapi seorang anak.Kemudian $\mathrm{K} \backslash$ kepedulian pemerintah selanjutnya diwujudkan dengan pembentukan Undang-Undang No. 23 Tahun 2002 tentang Perlindungan Anak. Kebijakan pemerintah, dalam Undang-undang Nomor 23 Tahun 2002 tentang Perlindungan Anak ini menjelaskan bahwa pelindungan anak adalah segala kegiatan untuk menjamin dan melindungi anak dan hak-haknya agar dapat hidup, tumbuh, kembang, dan

7 Christine dodingington mary Hilton, Pendidikan Berpusat Pada Anak Membangkitkan Kembali Tradisi Kreatif (PT:Indeks Jakarta 2010),. hlm 123 
berpartisipasi, serta optimal sesuaidengan harkat dan martabat kemanusiaan, serta mendapat perlindungan dari kekerasan dan diskriminasi.

Pemerintah Indonesiajuga telah meratifikasi konvensi ILO No: 138 mengenai batasan usia minimum untuk bekerja dengan UU No: 20/1999. Sebagai salah satu syarat dari proses ratifikasi, pemerintah Indonesia telah membuat deklarasi yang menyatakan bahwa “ batasan usia minimum untuk bekerja di Indonesia ialah 15 tahun". Namun konvensi ini sebenarnya memberikan banyak pengecualian, anak usia 1213 tahun juga masih diperkenankan melakukan berbagai pekerjaan ringan sejauh pekerjaan tersebut tidak menggangu tumbuh kembang anak secara fisik, moral, maupun intelektual mereka.Namun konvensi ini jelas menyatakan bahwa anak dibawah usia 18 tahun dilarang melakukan pekerjaan berbahaya

Menurut Abu Hurairah dalam rangka perlindungan terhadap anak sebagai pekerja, konvensi memuat beberapa asas yang antara lain; Asas penghapusan kerja anak, dirumuskan dalam Pasal 1 yang mengamanatkan kepada setiap anggota untuk mengambil kebijakan secara nasional untuk menjamin penghapusan kebijakan anak sebagai pekerja secara efektif. Selain itu, setiap anggota diwajibkan untuk secara progresif menaikan usia minimum untuk diperbolehkan bekerja sampai pada suatu tingkat yang sesuai dengan kebutuhan perkembangan fisik dan mental orang muda. ${ }^{8}$

\section{Peran dan Intervensi Pekerja Sosial dalam kasus Eksploitasi dan Pekerja Anak}

Peran dan intervensi pekerjaan social dalam kasus ini adalah membantu individu, kelompok masyarakat yang terlibat dalam kasus ini dan yang sedang menghadapi kasus tentang eksploitasi dan pekerja anak di Indonesia ini yang, masih sering terjadi dan menyebabakan keresahan masyarakat di akibatkan anak-anak yang masih dibawah umurlah yang menjadi korban pada kasus ini. Memberikan pertolongan dan pencerahan terhadap kasus ini. Dengan berbagai pendekatan -pendekatan yang digunakan dalam hal ini untuk mempermudah seorang pekerja social dalam menangani permasalahan yang sedang di hadapi klien .

Tujuan utama dari intervensi seorang pekerjaan social terhadap klien adalah memperbaiki fungsi sosial orang (individu, kelompok, masyarakat) yang merupakan sasaran perubahan. Ketika fungsi sosial seseorang berfungsi dengan baik, diasumsikan bahwa kondisi sejahtera akan semakin mudah bagi klien.

\section{Penutup}

Pemerintah telah melakukan berbagai upaya dalam mengatasi terjadinya eksploitasi dan pekerja anak

8 Abu Huraerah. Kekerasan Terhadap Anak, (Bandung: Nuansa,2006).Hlm. 40. 
, sehingga pemerintah melakukakan rekontruksi kebijakan sosial dengan mengeluarkan berbagai bentuk aturanaturan, keputusan dan kebijakankebijakan guna untuk melindungi hak anak itu sendiri. Sehinggan anak tidak lagi mendapatkan berbagai permaslahan yang akan mengganggu aktifitas tumbuh kembangnaya dalam masyarakat dan dapat menjamin keberlangsungan hidupnya secara normal. Akan tetapi upaya pemerintah dalam mengatasi permasalahan anak tersebut belum bisa berjalan secara maksimal, sesuai dengan apa yang kita harapkan bagi bangsa ini. Dalam kasus ini pemerintah telah menunjukkan kepedulianya terhadap kasus-kasus yang menimpa anak, dengan meminimalisir permasalahan ini secara bertahap dan dalam waktu jangka panjang untuk menuntaskannya, dan tidak angkat tangan begitu saja dalam mengatasi permasalahan yang dihadapi saat ini.

\section{Daftar Pustaka}

Bunga-bunga diatas Padas, Fenomena Pekerja Rumah Tangga Anak Di Indonesia. ILO/ IPEC 2004

Christine Dodingington Mary Hilton, Pendidikan Berpusat Pada Anak Membangkitkan Kembali Tradisi Kreatif.Jakarta: PT.Indeks 2010.
Suharto,Edi. Membangun Masyarakat Memberdayakan Rakyat, Bandung: PT.Raflika Aditama 2010.

Huraerah,Abu. Kekerasan Terhadap Anak, Nuansa: Bandung. 2006

Suharto,Edi. Analisis Kebijakan Publik, Bandung: Alfabeta, 2012.

Usman, Hardius dan Nachrowi D.N. (2004), Pekerja Anak Di Indonesia, Kondisi,Determinan danEksploitasi, Grasindo, Jakarta.

Bellamy ,Carol. 1997 Laporan Situasi Anak-Anak Di Dunia 1997, Unicef, Jakarta

Irwanto ,1999. Anak Yang Membutuhkan Perlindungan Khusus Di Indonesia: Analisis Situasi, Pusat Kajian Pembangunan Masyarakat, Universitas Katholik Atma Jaya, Jakarta

Sofyan, Ahmad. 1997. Kompleksitas Masalah Pekerja Anak, Populasi Vol.8 Nomor 2 Tahun 1997

Haryadi, Dedi,dkk. Buruh Anak dan Dinamika Industri Kecil, Alkatiga: Bandung

Sajagoyo ,Pudjiwati. Peranan Wanita Dalam Perkembangan Masyarakat, Jakarta: Yayasan Ilmu-Ilmu Sosial, CV Rajawali. 